\title{
Ischemic stroke in Morocco: a systematic review
}

\author{
Ahmed Kharbach ${ }^{2 *}$, Majdouline Obtel ${ }^{1,2}$, Laila Lahlou ${ }^{2,4}$, Jehanne Aasfara ${ }^{3}$, Nour Mekaoui ${ }^{2,5}$ and Rachid Razine ${ }^{1,2}$
}

\begin{abstract}
Background: The aim of this systematic review is to determine the epidemiological and etiological profiles, the influential factors of the prehospital delay, thrombolysis management, the acute and 3-month mortality rate and the genetic aspect of ischemic stroke in Morocco.

Methods: The present work is a systematic review that was conducted according to the recommendations of the "Preferred reporting items for systematic reviews and meta-analysis". We used Pubmed, Sciencedirect, Scopus, Clinicalkey, and Google scholar databases for the raking of the gray literature during the time frame 2009 and 2018. The protocol of the review was registered in the PROSPERO register (CRD42018115206).

These studies were analyzed based on: Age, sex ratio, risk factors, etiological profile according to Trial of ORG classification 10,172 in Acute Stroke Treatment, prehospital delay average and its influential factors, thrombolyzed patients' proportion, acute and 3-month mortality and the genetic factors of ischemic stroke in Morocco.

Results: Twenty-nine $(n=29)$ studies were selected. The average age ranged from $49 \pm 15.2$ to $67.3 \pm 9.9$ years old. Moreover, we reported male predominance within all ages in 13 studies. High blood pressure, diabetes, smoking and heart disease were the four identified main risk factors by the prementioned studies. Atherosclerosis and cardioembolic were the main described etiologies of cerebral ischemia, and the average prehospital time ranged from 26 to $61.9 \mathrm{~h}$. The proportion of thrombolysed patients ranged from $1.8 \%$ to $2.9 \%$, the mortality rate varied in the acute phase from 3 to $13 \%$, and the 3-month mortality ranged from 4.3 to $32.5 \%$. It is also important to highlight that most of these studies, which were conducted in hospital environment, have a reduced sample size and no confidence interval.
\end{abstract}

Conclusions: Ischemic stroke is affecting more likely the young population with male predominance. Moreover, the long prehospital delay and the low proportion of thrombolysed patients are alarming. This indicates the need to investigate in depth the key factors influencing the access to care for Moroccan patients in order to improve the management of this neurologic deficit in Morocco.

Keywords: Ischemic stroke, Trial of ORG classification 10,172 in acute stroke treatment classification, Prehospital delay, Thrombolysis, Morocco

\section{Background}

Stroke has become a major public health concern and a real growing burden on African countries [1, 2], regarding its cost on the social, psychological, and economic levels [3]. The incidence of stroke continues to increase in developing countries, including the North African region [4].

\footnotetext{
* Correspondence: kharbach.a.lbrce@gmail.com

${ }^{2}$ Laboratory of Biostatistics, Clinical Research and Epidemiology (LBRCE),

Faculty of Medicine and Pharmacy of Rabat, Mohamed V University, 10100

Rabat, Morocco

Full list of author information is available at the end of the article
}

From an etiological point of view, previous studies have described multiple causes of stroke [5]. According to the epidemiological survey conducted in the two metropolitan Moroccan cities (Casablanca and Rabat), ischemic stroke (IS) represented $70.9 \%$ of all types of stroke [6]. Multidisciplinary and fast approaches are highly required in term of therapeutic management since they are key determinants of the prognosis and evolution of the disease [7]. In addition, a major evolution in IS care management is occurring during the last years. The two main improvements are the approval of intravenous

(c) The Author(s). 2019 Open Access This article is distributed under the terms of the Creative Commons Attribution 4.0 International License (http://creativecommons.org/licenses/by/4.0/), which permits unrestricted use, distribution, and 
thrombolysis and the intra-arterial mechanical thrombectomy [8]. Stroke is thus considered as a critical challenge in terms of prevention and patients' management in acute phase in order to improve the mortality and morbidity of this pathology [7, 9].

In the context of low-and-middle income countries, and despite the enormous burden of stroke, only $15 \%$ of medical and fundamental research is dedicated to study and explore this medical condition compared to $85 \%$ in high-income countries [10]. Furthermore, in Morocco, there is a lack of data concerning the temporal patterns of the incidence or the long-term evolution of this debilitating disease [11].

Since ischemic stroke is largely preventable, it is important to study the epidemiological and other aspects of care to reduce the incidence rate and the resulting burden on our kingdom. It is important to highlight that this is the first systematic review of the literature on stroke to be conducted in Morocco. In this respect, the objective of this work was to evaluate, through the systematic review, the epidemiological and etiological profiles, influencing factors of the prehospital delay, thrombolysis management, mortality rate in the acute phase and at 3 months, along with the genetic aspect of IS in Morocco.

\section{Methods}

\section{Research strategy}

This systematic review was conducted in accordance with the methodological criteria of the Preferred reporting items for systematic reviews and meta-analyses (PRISMA) [12]. The protocol has been previously registered and published (PROSPERO: CRD42018115206/ http://www.crd.york.ac.uk/PROSPERO/display_record. php?ID=CRD42018115206).

This is a systematic review of the literature by adopting a multisource research strategy, consulting the databases of Pubmed, Sciencedirect, Scopus, Clinicalkey, and Google scholar for raking gray literature (National Scientific Research Works such as Master theses and PhD dissertations of medicine) between 2009 and 2018 (Last questioning on November, the 29th 2018).

The key words used were as follows: (Ischemic stroke) or (cerebral infarction) or (Cerebral ischemia) or (ischemic stroke) or (ischemic attack) or (Cerebral ischemia) or (Cerebral infarction) and (Morocco) or indicating specific cities of the kingdom.

Two authors (KA and OM) independently verified titles and abstracts to identify the to-be included studies. Complete articles of the potential studies were downloaded for a more detailed evaluation and the list of references in all relevant articles were examined for additional documents as well as for the citing papers. No restrictions were made on the language of publication.

\section{Inclusion and exclusion criteria}

1. Studies were conducted in Morocco and published after 2009 concerning IS.

2. Studies on the following data: age, sex ratio, risk factors, etiologic profile, prehospital delay and the management of cerebral ischemia including thrombolysis.

3. Studies on genetic polymorphisms related to the occurrence of cerebral ischemia in Morocco.

4. Studies on IS in patients aged less than 15 years old where cerebral venous thromboses have been excluded.

\section{Extraction and analysis of data}

The data extracted from the identified documents were the following: average age, sex ratio, risk factors, etiological profile according to the Trial of ORG classification 10,172 in Acute Stroke Treatment (TOAST) classification, prehospital delay, stroke management (thrombolysis), mortality rate at the acute phase and at 3 months according to the modified Rankin score, and genes involved in the occurrence of cerebral ischemia in Morocco.

\section{Risk of bias in individual studies}

Bias risk assessment was conducted by two authors independently through the use of "Quality Assessment Tool for Case Series Studies", "Quality Assessment Tool for Cross-Sectional Studies" and "Newcastle-Ottawa Quality Assessment Scale Case-Control Studies".

Two reviewers (KA and OM) assessed the methodological quality of the studies independently and then the agreement between the two examiners' results was analyzed by the Kappa statistical coefficient ( $\mathrm{\kappa}$ ).

\section{Results}

Twenty-nine $(n=29)$ studies were selected (The flow chart is shown in Fig. 1). Based on study type: Full original papers $(n=13)$, conference abstracts $(n=6)$, medical theses $(n=10)$. By locations: Rabat $(n=5)$, Casablanca $(n=7)$, Casablanca and Rabat $(n=1)$, Marrakech $(n=7)$, Fez $(n=8)$, and Meknes $(n=1)$. According to the study design: $(n=15)$ were retrospective case series, $(n=8)$ were prospective case series, $(n=1)$ were prospective cross sectional study, and $(n=5)$ were prospective case-control studies. According to the age of the target population of the selected studies, $(n=25)$ studies targeted all ages combined (More than 15 years old) and $(n=4)$ studies focused on the young population (15-45 years old). All studies were hospital series.

The Kappa statistical coefficient was $(\kappa=0.64)$. The Quality Rating of "case series", "cas-control" and "crosssectional" studies were considered "good" with an 


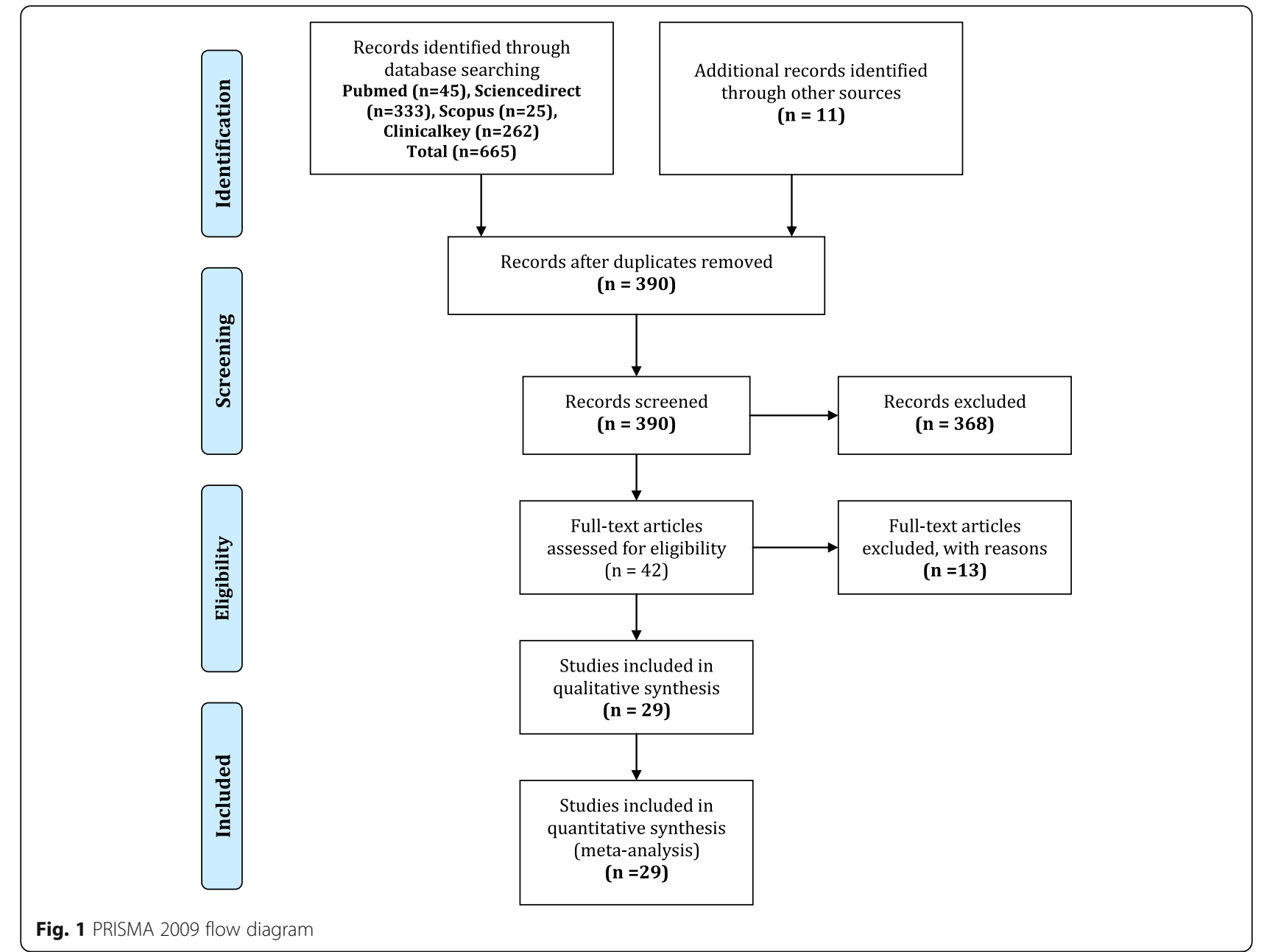

average score of 7.5/9 (the results of the methodological evaluation of case series studies are shown in Table 1).

\section{Mean age and sex ratio of patients with ischemic stroke in Morocco}

Twenty-three studies focusing on IS in all age groups revealed an average age ranging from $49 \pm 15.2$ to $67.3 \pm 9.9$ years old. Thus, the average age is listed in the fifth and sixth decade [13, 15-18, 20, 21, 23-28, 32-41]. However, two studies did not specify the average age of patients. The first study was conducted by Chraa (2010), who reported that the age was below 45 years old in $36 \%$ of cases and more than 45 years old in $64 \%$ of cases, while the second by Bourazza et al. (2013) indicated an age between the two extremes of 24 and 104 years old $[19,30]$.

As for the sex ratio $(n=13)$, studies revealed a male predominance with a ratio ranging between 1.23 and 3.45 [16-19, 24-26, 36-40, 42]. A ratio of 1 has been reported only in $(n=3)$ studies [23, 40,41]. Similarly, a slight female predominance with a ratio between 0.7 and 0.9 was reported in $(n=9)$ studies [13, 20, 21, 25, 28, 30, 32-34].
Concerning IS in early adulthood, four studies $(n=4)$ included patients aged between 15 and 45 years old. The first was a study by Mbagui (2009) with an age ranging between 15 and 45 years old, the second of Ibouajbane (2014) between 16 and 45, the third of Chraa et al. (2014) with an age between 18 and 45 and the fourth of Allaoui et al. (2018), which included all patients admitted to internal medicine under the age of 45 $[14,22,29,31,43]$.

According to the studies of IS in young people, the average age ranged from $28.3 \pm 4.2$ to 39 years old (Extremes: 16-45 years old) [14, 22, 29, 31, 43].

Concerning the sex-ratio of IS in young cases, $(n=2)$ studies reported values less than 1 . The first is attributable to the one by Ibouajbane (2014) with a clear female predominance (sex -ratio of 0.4) [31], and the second was performed by Allaoui et al. (2018) showing a slight female predominance with a sex ratio of 0.7 [43].

Male predominance was described by Chraa et al. (2014) with a sex ratio of 1.4 [22]. In addition, the Mbagui (2009) study did not show any significant difference between the two genders [29]. 
Table 1 Quality assessment tool for case series studies

\begin{tabular}{|c|c|c|c|c|c|c|c|c|c|c|c|c|c|c|c|c|c|c|c|c|c|c|c|}
\hline Criteria & [13] & {$[14]$} & {$[15]$} & [16] & [17] & [18] & [19] & [20] & [21] & [22] & [23] & [24] & [25] & [26] & [27] & [28] & [29] & [30] & [31] & [32] & [33] & [34] & [35] \\
\hline $\begin{array}{l}\text { 1. Was the study } \\
\text { question or objective } \\
\text { clearly stated? }\end{array}$ & 1 & 1 & 1 & 1 & 1 & 1 & 1 & 1 & 1 & 1 & 1 & 1 & 1 & 1 & 1 & 1 & 1 & 1 & 1 & 1 & 1 & 1 & 1 \\
\hline $\begin{array}{l}\text { 2. Was the study } \\
\text { population clearly and } \\
\text { fully described, } \\
\text { including a case } \\
\text { definition? }\end{array}$ & 1 & 1 & 1 & 1 & 1 & 1 & 1 & 1 & 1 & 1 & 1 & 1 & 1 & 1 & 1 & 1 & 1 & 1 & 1 & 1 & 1 & 1 & 1 \\
\hline $\begin{array}{l}\text { 3. Were the cases } \\
\text { consecutive? }\end{array}$ & 1 & 1 & 1 & 1 & 1 & 1 & 1 & 1 & 1 & 1 & 1 & 1 & 1 & 1 & 1 & 1 & 1 & 1 & 1 & 1 & 1 & 1 & 1 \\
\hline $\begin{array}{l}\text { 4. Were the subjects } \\
\text { comparable? }\end{array}$ & 1 & 1 & 1 & 1 & 1 & 1 & 1 & 1 & 1 & 1 & 1 & 1 & 1 & 1 & 1 & 1 & 1 & 1 & 1 & 1 & 1 & 1 & 1 \\
\hline $\begin{array}{l}\text { 5. Was the } \\
\text { intervention clearly } \\
\text { described? }\end{array}$ & 1 & 1 & 1 & 1 & 1 & 1 & 1 & 0 & 0 & 1 & 1 & 0 & 1 & 1 & 1 & 1 & 1 & 0 & 1 & 1 & 1 & 1 & 1 \\
\hline $\begin{array}{l}\text { 6. Were the outcome } \\
\text { measures clearly } \\
\text { defined, valid, reliable, } \\
\text { and implemented } \\
\text { consistently across all } \\
\text { study participants? }\end{array}$ & 1 & 0 & 0 & 1 & 1 & 1 & 0 & 0 & 0 & 1 & 0 & 1 & 1 & 1 & 1 & 1 & 1 & 1 & 1 & 1 & 1 & 1 & 1 \\
\hline $\begin{array}{l}\text { 7. Was the length of } \\
\text { follow-up adequate? }\end{array}$ & 1 & 1 & 0 & 1 & 0 & 1 & 1 & 1 & 1 & 1 & 1 & 1 & 0 & 1 & 1 & 0 & 1 & 1 & 1 & 1 & 1 & 1 & 1 \\
\hline $\begin{array}{l}\text { 8. Were the statistical } \\
\text { methods well- } \\
\text { described? }\end{array}$ & 1 & 0 & 0 & 0 & 0 & 1 & 0 & 0 & 0 & 0 & 0 & 0 & 0 & 0 & 0 & 0 & 1 & 0 & 0 & 1 & 1 & 0 & 0 \\
\hline $\begin{array}{l}\text { 9. Were the results } \\
\text { well-described? }\end{array}$ & 1 & 1 & 1 & 1 & 1 & 1 & 1 & 1 & 1 & 1 & 1 & 0 & 1 & 1 & 1 & 1 & 1 & 1 & 1 & 1 & 1 & 1 & 1 \\
\hline Score & 9 & 7 & 6 & 8 & 6 & 9 & 7 & 6 & 6 & 8 & 7 & 6 & 7 & 8 & 8 & 7 & 9 & 7 & 8 & 9 & 9 & 8 & 8 \\
\hline
\end{tabular}

\section{Risk factors for ischemic stroke in Morocco according to the selected studies}

Studies included in the present critical review of the literature have revealed several risk factors associated with cerebral ischemia in the local populations of interest. Indeed, high blood pressure (HBP), diabetes, smoking and heart disease were the four main risk factors listed and are as follows: HBP was reported in $(n=20)$ studies (31 to $65.4 \%)[13,15,17,18,20,21,23,25-28,30,33,35-$ $38,40-42]$, diabetes in $(n=20)$ studies $(12-41.8 \%)$ [13, $15,17,18,20,21,23,25-28,30,33,35-38,40-42]$, cardiac diseases in 14 studies (7-44.3\%) [13, 15, 17, 20, 21, $23,25-28,30,33,35,42]$, atrial fibrillation as associated heart disease was specified in 9 studies $(2,5-22 \%)$, and smoking in $(n=19)$ studies $(4-41.8 \%)[13,15,17,18,20$, $21,23,25-28,30,33,35,37,38,40-42]$.

In addition to these risk factors, other risk factors have been reported such as dyslipidemia in $(n=16)$ studies $(0-$ $61.8 \%)$ [13, 15, 17, 18, 20, 23, 25-28, 30, 33, 35-37, 42], obesity in $(n=6)$ studies $(10.7-26.1 \%)[13,17,18,26,30$, $35]$, the notion of a previous stroke was noted in $(n=10)$ hospital series (5-26.6\%) [13, 15, 23, 25-28, 30, 32, 35], alcoholism in $(n=10)$ studies $[13,15,20,25,32,33,35,38$, $40,41]$, oral contraception in $(n=3)$ studies $(6.6-12.2 \%)$ $[30,32,33]$, and migraine in a single study at $6.5 \%$ [30].
Concerning the young population, the reported risk factors were smoking in $(n=4)$ studies $(5-40.6 \%)$ [14, $22,29,31]$, HBP in $(n=4)$ studies $(8 \%-49.2 \%)[14,22$, $29,31,43]$, oral contraception in $(n=4)$ studies (12$31.2 \%)[14,22,29,31,43]$, cardiac diseases only by Chraa et al. (2014) with a percentage of $17.9 \%$ [22], diabetes in $(n=4)$ studies $(7.5-13.2 \%)$ [14, 22, 29, 31, 43], migraine in ( $n=4)$ studies $(1.5-24 \%)$ [14, 22, 29, 31, 43], dyslipidemia in $(n=3)$ studies $(0-15.3 \%)$ [22, 29, 31], alcoholism in $(n=3)$ studies $(5-8 \%)[22,29,31]$, obesity only $(n=1)$ by the study of Ibouajbane (2014) with a percentage of $2.5 \%$ [31], previous strokes history in $(n=2)$ studies by Chraa et al. (2014) and by Ibouajbane (2014) with a percentage of $2.3 \%$ and $2.5 \%$, respectively [22, 31], the first-degree family history of stroke was reported in a single study by Allaoui et al. (2018) with a percentage of 25\% [43] and pregnancy was reported as key risk factor in $(n=2)$ studies, conducted by Mbagui (2009) and Chraa et al. (2014) with percentages of $0.9 \%$ and $1.5 \%$ respectively $[22,29]$ (The results are detailed in Tables 2 and 3 ).

Genetic risk factors for ischemic stroke in Moroccan studies The present systematic review includes only $(n=5)$ studies focusing on the genetic factors associated with IS in Morocco. 


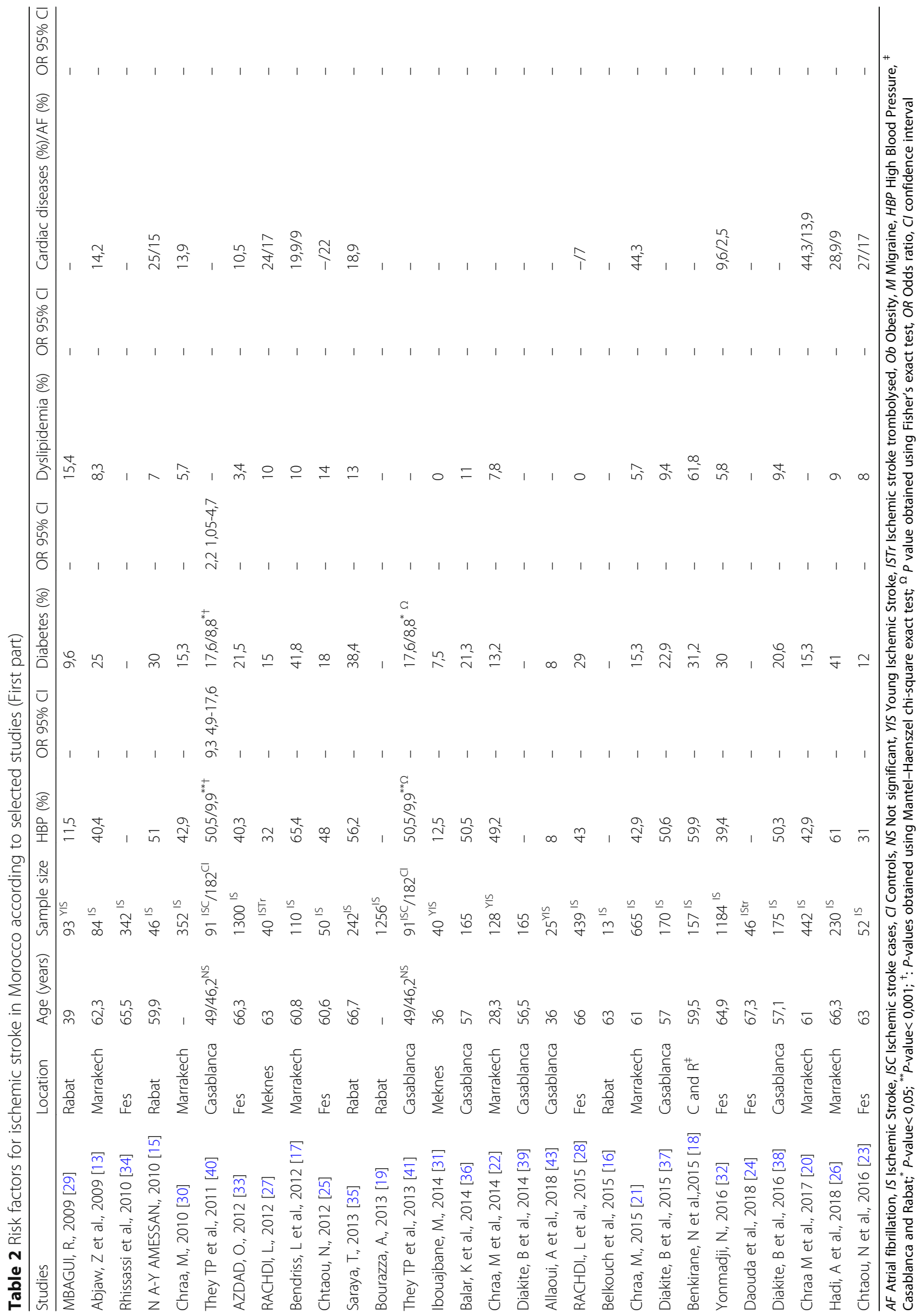




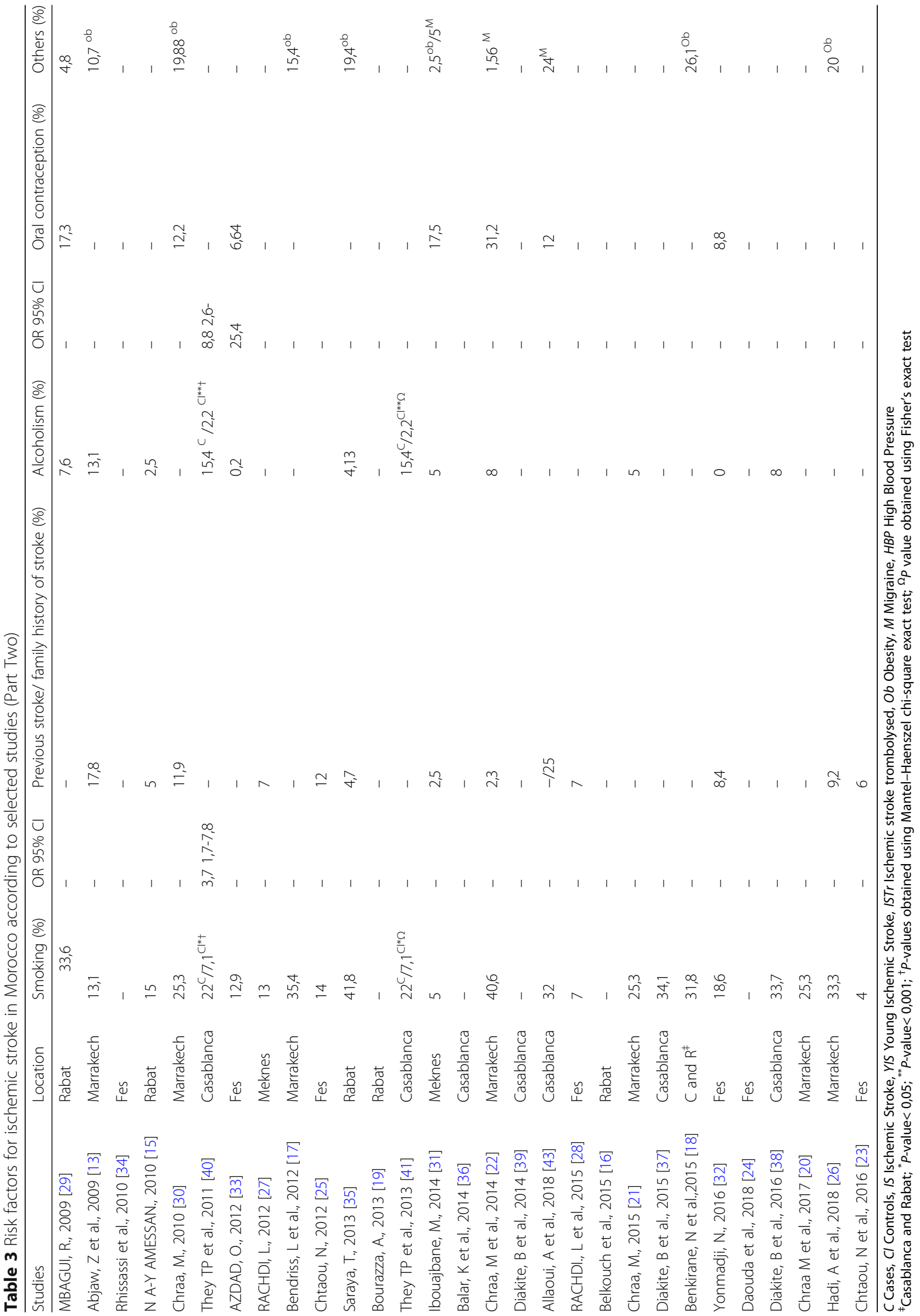


The first study by They et al. (2011) suggested that the MTHFR C677T variant could be a determinant of the atherothrombotic event of IS in Morocco [40]. The same team, They et al. (2013) demonstrated an interaction between MTHFR C677TT and F2 20210GA polymorphisms linked to an increased risk of IS [35]. The third study by Diakite et al. (2014) suggested another statistically significant association between G894 $T$ polymorphism at the level of $e N O S$ gene and IS in the recessive, dominant and additive models [39].

In addition, another genetic study by Diakite et al. (2015) evaluated the association of the FVF C2491T mutation with the risk of IS, suggesting that carriers of the mutated $\mathrm{T}$ allele were associated with a high risk of IS. But this risk was 8.95 times higher when the subject had the TT genotype $(P<0.0001)$ and 4.08 times higher with the CT genotype, and they concluded that the FVF C2491T mutation could be a genetic risk factor for IS in the Moroccan population [37].

The fourth genetic research was conducted by Diakite et al. (2016) on T-1131C APOA5 polymorphism; he observed a modest risk of IS with CC and $C$ alleles. In addition, the same study explored also the risk of IS related to SG13S114 ALOX5AP and showed a significant association with TT and T alleles. Despite the reduced sample size, variants of T-1131C APOA5 and SG13S114 could be considered as an independent genetic risk factor IS in the Moroccan population [38]. Furthermore, the fifth study by Balar (2014), showed that MTHFR gene (patients with MTHFR CT/ TT patients without CT/TT) and other factors (sex, age, HBP, diabetes, smoking, alcoholism, dyslipidemia) did not reveal significant correlation [36]. (Results are detailed in Table 4).

\section{TOAST etiological classification of ischemic stroke in} Moroccan studies

The most prominent etiology is atherosclerosis of large arteries according to $(n=16)$ studies $(16-57.8 \%)[16,17,23$, $25-28,30,32-35,37-40]$. The cardioembolic origin comes second in $(n=17)$ studies $(8.8-50 \%)[16,17,20,23,25-28$, $30,32-35,37-40]$, undetermined causes were present in $(n=12)$ studies $(5.5-34 \%)[16,17,23,25-28,30,32,33$, $35,40]$, lacunar ischemic stroke was reported in $(n=12)$ studies $(0-39 \%)[16,17,23,26,28,30,32,35,37-40]$ and other identified causes are recorded in $(n=13)$ studies (0-27.4\%] [16, 23, 25, 27, 28, 30, 32, 33, 35, 37-40].

Concerning the etiological category "Other identified causes", five studies have specified the pathologies involved in the ontogeny and the occurrence of ischemic stroke conditions [25, 27, 28, 30, 35]. The first study was performed by Chraa (2010), and has reported 14 cases of syphilitic arteritis, 12 cases related to disorders of clotting factors, 5 cases of arterial dissection, 4 cases of systemic diseases, 4

Table 4 Results of published studies on the association between six genes and ischemic stroke in Morocco

\begin{tabular}{|c|c|c|c|c|c|c|c|c|}
\hline Study & Cases & Controls & Genes & Mutations & Genotypes & Methods & $\begin{array}{l}\text { Odds Ratio 95\% } \\
(\mathrm{Cl})\end{array}$ & $P$ value \\
\hline \multirow[t]{2}{*}{ They, TP et al., 2011 [40] } & \multirow[t]{2}{*}{91} & \multirow[t]{2}{*}{182} & \multirow[t]{2}{*}{ MTHFR } & \multirow[t]{2}{*}{ C677T } & T allele and Stroke & \multirow[t]{2}{*}{ PCR } & $1.1(0.59-2.04)$ & $0.303^{\Omega}$ \\
\hline & & & & & $\begin{array}{l}\text { T allele and } \\
\text { atherothrombotic } \\
\text { subtype stroke }\end{array}$ & & $2.1(1.17-3.8)$ & $0.012^{\Omega}$ \\
\hline They, TP et al., 2013 [41] & 91 & 182 & $\begin{array}{l}\text { MTHFR } \\
\text { F2 }\end{array}$ & $\begin{array}{l}\text { C677T } \\
\text { G20210A }\end{array}$ & $\begin{array}{l}\text { 677T//CC } \\
20210 G A / G G\end{array}$ & $\begin{array}{l}\text { PCR- } \\
\text { RFLP }\end{array}$ & $\begin{array}{l}4.99(1.75-14.2) \\
5.29(1.63-17.1)\end{array}$ & $\begin{array}{l}0.001^{\Pi} \\
0.005^{\Sigma}\end{array}$ \\
\hline \multirow{3}{*}{$\begin{array}{l}\text { Diakite, B et al., } 2014 \\
\text { [39] }\end{array}$} & \multirow[t]{3}{*}{165} & \multirow[t]{3}{*}{182} & \multirow[t]{3}{*}{ eNOS } & \multirow[t]{3}{*}{ G894T } & TT vs. GG + GT Recessive & \multirow{3}{*}{$\begin{array}{l}\text { PCR- } \\
\text { RFLP }\end{array}$} & $2,68(1,08-6,70)$ & $0.034^{\Delta}$ \\
\hline & & & & & GT + TT vs. GG Dominant & & $1.78(1,16-2,73)$ & $0.009^{\Delta}$ \\
\hline & & & & & T vs. G Additive models & & $1.71(1,21-2,43)$ & $0.003^{\Delta}$ \\
\hline \multirow{3}{*}{$\begin{array}{l}\text { Diakite, B et al., } 2015 \\
\text { [37] }\end{array}$} & \multirow[t]{3}{*}{170} & \multirow[t]{3}{*}{211} & \multirow[t]{3}{*}{$F V$} & \multirow[t]{3}{*}{ C2491T } & T allèle & \multirow{3}{*}{$\begin{array}{l}\text { PCR- } \\
\text { RFLP }\end{array}$} & $3.77(2.70-5.25)$ & \multirow{3}{*}{$\begin{array}{l}< \\
0.0001^{* *}\end{array}$} \\
\hline & & & & & $C T$ & & $4.08(2.55-6.49)$ & \\
\hline & & & & & $\pi$ & & $8.95(4.15-19.29)$ & \\
\hline \multirow{4}{*}{$\begin{array}{l}\text { Diakite, B et al., } 2016 \\
\text { [38] }\end{array}$} & \multirow[t]{4}{*}{175} & \multirow[t]{4}{*}{201} & \multirow[t]{2}{*}{ APOA5 } & \multirow[t]{2}{*}{ T1131C } & CC & \multirow{2}{*}{$\begin{array}{l}\text { PCR- } \\
\text { RFLP }\end{array}$} & $2.86(1.24-6.58)$ & \multirow[t]{2}{*}{0.014} \\
\hline & & & & & C allele & & $1.54(1.01-2.33)$ & \\
\hline & & & \multirow[t]{2}{*}{ ALOX5AP } & \multirow[t]{2}{*}{ SG13S114 } & $\pi$ & \multirow{2}{*}{$\begin{array}{l}\text { PCR- } \\
\text { RFLP }\end{array}$} & $2.57(1.49-4.83)$ & 0.009 \\
\hline & & & & & T allele & & $1.59(1.16-2.19)$ & 0.008 \\
\hline Balar, K et al., 2014 [36] & $165^{\dagger}$ & & MTHFR & $\underset{\neq}{\text { Facteurs de risque }}$ & $\mathrm{CT} / \mathrm{TT}$ & - & - & NS $\wedge$ \\
\hline
\end{tabular}


cases of migraine, 1 case of chemotherapy, and 1 case of human immunodeficiency virus. The second study was conducted by Chtau (2012) and revealed that $2 \%$ of all cases were related to arterial dissections. The third was done by Rachdi (2012) and who reported 1 case of Vaquez disease. The fourth study by Saraya (2013) revealed 1 case of polycythemia, 1 case with interhemispheric Meningioma, a toxic IS after Cannabis consumption, and an IS after cerebral angiography as part of the assessment of a C3 Neuroma. The last study was conducted by Rachdi (2015) and showed that $5 \%$ of all cases were related to carotid stenosis when it was greater than $50 \%$. However, six other studies did not identify the "Other identified causes" [32, 33, 37-40].

With respect to the young population (15-45 years old), the undetermined causes were identified in four studies. The first study was by Mbagui (2009) with a percentage of 29\% [29]. The second by Chraa et al. (2014) with a percentage of $40.6 \%$ [22]. The third by Ibouajbane (2014); 55\% of all cases were linked to undetermined causes [31]. Finally, Allaoui et al. (2018) reported a percentage of $24 \%$ [43].

The IS of cardioembolic origin was also highlighted in four studies; the first study was performed by Mbagui (2009) and reported a percentage of $21.5 \%$ [29]. The second by Ibouajbane (2014) showed a percentage of $15 \%$ [31]. Interestingly, the third study was by Chraa et al. (2014) revealed that $33.6 \%$ of all cases were present with cardioembolic source [22]. By contrast, the fourth study by Allaoui et al. (2018) reported a percentage of $4 \%$ [43].

As for the other determinant causes, they were identified in $(n=4)$ studies (Mbagui, 2009; Chraa et al., 2014; Ibouajbane, 2014; Allaoui et al., 2018) with 21.5\%, 14.1\%, $15 \%$ and $72 \%$ respectively $[22,29,31,43]$.

Concerning the details on the etiological class "other specific causes", four studies specified the causes involved in the occurrence of IS in young population. The first by Mbagui (2009) highlighted the implication of blood diseases, vasculitis, oral contraception and carotid dissections with percentages of 35\%, 25\% (2 cases of Behcet, 1 case of Takayashu, 2 cases of undetermined vasculitis), and 15\%, respectively. In addition, 1 case of sneddon syndrome, and 1 post-partum cases were reported [29].

The second by Ibouajbane (2014), angiitis accounted for $5 \%$ of cases, hematological disorders for $5 \%$ of the cases, 1 case was observed during pregnancy and especially during the sixth month, and thrombophlebitis in another case [31]. The third by Chraa et al. (2014) described 11 cases of syphilis, 3 cases of carotid dissections, 2 cases of coagulation protein deficiency (C), 1 case of sneddon syndrome, and 1 case of antiphospholipids' antibody syndrome [22].

The fourth study by Allaoui et al. (2018) described a percentage of determinate causes of $72 \%$. The etiologies in this study were dominated by systemic lupus (32\%) associated with antiphospholipid syndrome (80\%), Behcet's disease (16\%), Takayasu's disease (12\%) [43].

With respect to atherosclerosis of large arteries, it was reported in $(n=3)$ studies; Chraa et al. (2014), Ibouajbane (2014) and Mbagui (2009) with proportions respectively of $11.7 \%, 12.5 \%$ and $25.8 \%$ [22, 29, 31].

Lacunar IS was found in $(n=2)$ studies, including Mbagui (2009) and Ibouajbane (2014) with ratios of 2.1 and $2.5 \%$, respectively $[29,31]$. In Allaoui et al. study (2018), TOAST III (lacunary) patients were 73\% smokers, $8 \%$ had type II diabetes and/or High blood pressure, and $12 \%$ had oestroprogestative contraception at the time of diagnosis [43]. (Results are detailed in Table 5).

\section{Prehospital delay in patients with ischemic stroke in Morocco}

Since the notion of time is crucial in the management of cerebral ischemia, $(n=5)$ studies evaluated the prehospital delay, which consists of the time extending between the time of the symptoms onset and the patient arrival to the emergency department of the different hospital structures [26, 28, 32-34]. In this perspective, a minimum prehospital average delay was $26 \mathrm{~h}$ [Extremes: 15 Minutes- 8 months] according to the study by Azdad (2012) [33] and a maximum mean prehospital delay $61.9 \mathrm{~h}$ [Extreme: $0.5 \mathrm{~h}-216 \mathrm{~h}$ ] which was listed in the Yonmadji (2016) study [32]. (The results are detailed in Table 6).

Concerning the consultation period of young patients, It was assessed in two studies [29, 31]. Mbagui (2009) and Ibouajbane studies (2014) reported 134.4 $\mathrm{h}$ and 342 h, respectively [29, 31]. Moreover, Allaoui et al. (2018) showed that the delay between the onset of symptoms and the performance of the first cerebral imaging exceeded $12 \mathrm{~h}$ in $100 \%$ of cases [43]. No study investigated the factors influencing the consultation and admission time of patients with IS.

\section{The percentage of patients with thrombolyzed ischemic stroke in Morocco}

Four studies conducted at the neurology department of the Hassan II University Hospital of Fez had focused on the thrombolysis management. The proportion of thrombolysed patients ranged from $1.8 \%$ in the Azdad study (2012) [33] to $2.9 \%$ in the Rachdi (2015) study [28]. In addition, two studies by Yonmadji (2016) and Daouda et al. (2018) revealed two medium proportions of thrombolysed patients of $1.94 \%$ and $2.8 \%$, respectively $[24,32]$.

\section{Mortality in the acute phase and mortality in the chronic phase (3 months) in Morocco}

Six studies reported the mortality rates in the acute phase, ranging from 3\% in Yonmadji (2016) study to 
Table 5 TOAST etiological classification of ischemic stroke according to selected studies

\begin{tabular}{|c|c|c|c|c|c|c|}
\hline Studies & $\begin{array}{l}\text { Sample } \\
\text { size }\end{array}$ & $\begin{array}{l}\text { Atherosclerosis of large } \\
\text { arteries (\%) }\end{array}$ & $\begin{array}{l}\text { Cardio-embolic } \\
\text { Stroke (\%) }\end{array}$ & $\begin{array}{l}\text { Occlusion of small vessels } \\
\text { (Lacunar) (\%) }\end{array}$ & $\begin{array}{l}\text { Other determinate causes } \\
\text { of stroke (\%) }\end{array}$ & $\begin{array}{l}\text { Undetermined } \\
\text { causes of } \\
\text { stroke (\%) }\end{array}$ \\
\hline Chraa, M., 2010 [30] & 352 & 32,1 & 28,4 & 7,38 & 11,65 & 20,45 \\
\hline Mbagui., 2009 [29] & $93^{\mathrm{YIS}}$ & 25,81 & 21,51 & 2,15 & 21,51 & 29,03 \\
\hline $\begin{array}{l}\text { Chtaou, N et al., } \\
2016 \text { [23] }\end{array}$ & 52 & 32 & 50 & 0 & 0 & 18 \\
\hline $\begin{array}{l}\text { Chtaou, N., } 2012 \\
{[25]}\end{array}$ & 50 & 44 & 28 & - & 2 & 26 \\
\hline $\begin{array}{l}\text { Yonmadji, N., } 2016 \\
\text { [32] }\end{array}$ & 1184 & 57,8 & 21,4 & 10 & 5,25 & 5,55 \\
\hline $\begin{array}{l}\text { Diakite, B et al., } \\
2015 \text { [37] }\end{array}$ & 170 & 39,4 & 27,1 & 6,5 & 27,1 & - \\
\hline $\begin{array}{l}\text { Belkouch et al., } \\
2015 \text { [16] }\end{array}$ & 13 & 41,3 & 27 & 22 & 0 & 9,7 \\
\hline $\begin{array}{l}\text { Hadi, A et al., } 2018 \\
\text { [26] }\end{array}$ & 230 & 16 & 32 & 34 & - & 18 \\
\hline $\begin{array}{l}\text { Diakite, B et al., } \\
2016 \text { [38] }\end{array}$ & 175 & 39,4 & 26,9 & 6,3 & 27,4 & - \\
\hline $\begin{array}{l}\text { Rachdi, L., } 2012 \\
\text { [27] }\end{array}$ & 40 & 39 & 43,9 & - & 2,5 & 14,6 \\
\hline $\begin{array}{l}\text { Ibouajbane., } 2014 \\
\text { [31] }\end{array}$ & $40^{Y / S}$ & 12,5 & 15 & 2,5 & 15 & 55 \\
\hline $\begin{array}{l}\text { Chraa, M et al., } \\
2014 \text { [22] }\end{array}$ & $128^{\mathrm{YIS}}$ & 11,72 & 33,59 & - & 14,06 & 40,62 \\
\hline $\begin{array}{l}\text { Diakite, B et al., } \\
2014 \text { [39] }\end{array}$ & 165 & 56,36 & 32,12 & 4,84 & 6,66 & - \\
\hline $\begin{array}{l}\text { Bendriss, L et al., } \\
2012 \text { [17] }\end{array}$ & 110 & 28 & 18 & 39 & - & 14,5 \\
\hline $\begin{array}{l}\text { Chraa, M et al., } \\
2017 \text { [20] }\end{array}$ & 442 & - & 28,4 & - & - & - \\
\hline Saraya, T., 2013 [35] & 242 & 18,6 & 25,6 & 17,8 & 20,3 & 17,8 \\
\hline $\begin{array}{l}\text { They TP et al., } 2011 \\
\text { [40] }\end{array}$ & 91 & 46,2 & 8,8 & 26,4 & 12,1 & 6,6 \\
\hline $\begin{array}{l}\text { Azdad, O., } 2012 \\
\text { [33] }\end{array}$ & 1300 & 53,8 & 30,7 & - & 1 & 13,8 \\
\hline $\begin{array}{l}\text { Rachdi, } L \text { et al., } \\
2015 \text { [28] }\end{array}$ & 439 & 21 & 24 & 16 & 5 & 34 \\
\hline $\begin{array}{l}\text { Rhissassi et al., } \\
2010 \text { [34] }\end{array}$ & 342 & 52,1 & 27,6 & - & - & - \\
\hline $\begin{array}{l}\text { Allaoui, A et al., } \\
2018 \text { [43] }\end{array}$ & $25^{\mathrm{Y} / \mathrm{S}}$ & - & 4 & - & 72 & 24 \\
\hline
\end{tabular}

YIS: Ischemic stroke of young adult (15-45 years)

13\% for Chraa (2010) study. In addition, four studies by Saraya (2013), Rhissassi et al. (2010), Chtaou (2016) and Azdad (2012) revealed intermediate values of 5.8\%, 9.9\%, $10 \%$ and $10.8 \%$, respectively [23, 30, 32-35].

The rate of mortality after 3 months onset of the disease was reported in seven studies. Three studies by Bendriss et al. (2012), Rachdi (2015), and Hadi (2018) reported respectively the mortality rates of $5.4 \%, 10 \%$, and $8 \%$. Four studies by Daouda et al.
(2018), Yonmadji (2016), Chtaou (2016), and Rachdi (2012), respectively reported mortality rates of $4.3 \%$, $21.7 \%, 29 \%$, and $32.5 \%$ in IS treated with thrombolysis $[17,23,24,26-28,32]$.

The mortality during the acute phase in the young population was indicated in $(n=3)$ studies. The first from Ibouajbane (2014) stated a mortality rate of $0 \%$ [31], the second by Mbagui (2009) at 1.1\% [29] and the third by Chraa et al. (2014) with a mortality rate of $16.4 \%$ [22]. 
Table 6 Mean prehospital stroke delay (symptom onset to emergency department arrival) and percent arriving in 3, and after $24 \mathrm{~h}$ in Morocco publication

\begin{tabular}{|c|c|c|c|c|c|c|}
\hline \multirow[t]{2}{*}{ Studies } & \multirow[t]{2}{*}{ Study dates } & \multirow[t]{2}{*}{ Location } & \multirow{2}{*}{$\begin{array}{l}\text { Population } \\
\text { reported } \\
\text { on }\end{array}$} & \multirow{2}{*}{$\begin{array}{l}\text { Delay } \\
\text { in } \\
\text { hours }\end{array}$} & \multicolumn{2}{|c|}{ Per cent arriving in } \\
\hline & & & & & $<3 h$ & $>24 h$ \\
\hline Rhissassi et al., 2010 [34] & During the year 2009 & UHC Hassan II Fes & $342^{15}$ & 61 & - & - \\
\hline N A-Y AMESSAN., 2010 [15] & November 2009 to April 2010 & SH Rabat & $46^{15}$ & - & 28 & - \\
\hline Chraa, M., 2010 [30] & January2000 to December2009 & UHC Marrakech & $352^{\text {is }}$ & - & 5 & - \\
\hline AZDAD, O., 2012 [33] & $01 / 01 / 2009$ to $01 / 2 / 2010$ & UHC Hassan II Fes & $1300^{\mathrm{IS}}$ & 26 & 9,5 & - \\
\hline Bendriss, L et al., 2012 [17] & January 2005 and August 2008 & Cardiology MHAM & $110^{\mathrm{IS}}$ & - & - & 41 \\
\hline Saraya, T., 2013 [35] & January2009 to December 2011 & MVMTH Rabat & $242^{15}$ & - & 4,5 & - \\
\hline RACHDI, L et al., 2015 [28] & June 2014 and December 2014 & UHC Hassan II Fes & $439^{\text {Is }}$ & 27 & - & - \\
\hline Yonmadji, N., 2016 [32] & January2013 to December 2014 & UHC Hassan II Fes & $1184^{\text {is }}$ & 61,9 & $12,2^{\mathrm{a}}$ & 68,3 \\
\hline Hadi, A., 2018 [26] & January2010 to December 2014 & Cardiology MHAM & $230^{\mathrm{IS}}$ & 36 & - & - \\
\hline
\end{tabular}

IS Ischemic stroke, UHC University Hospital Center, SH Specialty Hospital, MHAM Military Hospital Avicenna Marrakech, MVMTH Mohamed V Military and Training Hospital

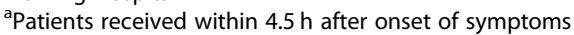

For the mortality after 3 months, no study elucidated this parameter.

\section{Discussion}

The average onset age of IS in Morocco was between $49 \pm 15.2$ and $67.3 \pm 9.9$ years old. The studies by Mbagui (2009), Chraa (2010) and Chraa et al. (2014) showed that the onset of IS occurs in 12.3\%, 28.9\% and 36\% respectively of the population under $45[22,29,30]$. The early onset of IS in Morocco according to the studies could probably be due to the young age of the Moroccan population and the low percentage of the elderly (over 60 years old), which represents $9.4 \%$ according to the results of the last national census of the population of 2014 [17, 30, 44]. The young age could be explained by the high frequency of embolic heart disease, rheumatic heart disease and sexually transmitted infections (syphilis, and acquired immunodeficiency syndrome) in Morocco [22, 33]. In addition, cardioembolic disease is considered as the leading cause of IS in the young population in our country due to the preponderance of rheumatic heart disease [43]. Similarly, it may also be due to the very high level of consanguinity and the significant association with the incidence of health conditions in the Moroccan population [45].

Furthermore, the average onset age of cerebral ischemia in Morocco is still lower with respect to the average age of patients admitted for IS in France in 2014 (74 \pm 15 years old) [46] and in comparison to the average age identified in a systematic review in the Arab countries (58.5 and 63 years old) [11]. Besides, the average age of the young population ranged between 28 and 39 years, which is in accordance with the results reported in other North African and the Middle Eastern countries [4749]. Since Morocco is a country from the Middle East and North Africa region (MENA), the average age reported in Moroccan studies is lower than the one described in non-MENA countries. This confirms the results obtained from the results of Safe Implementation of Treatments in Stroke (SITS)-MENA register (in MENA 55 years versus 73 years in Non-MENA) [50].

Most Moroccan studies have reported male predominance, consistent with the results of a literature review in the Arab world, which indicated that men were most often victims of stroke (between 55.9 and 75\%) [11].

These findings are also consistent with the results of a literature review at the level of Eastern Mediterranean countries, which has explored higher prevalence of stroke between men compared to women with a sex ratio up to 3.5 [51]. Moreover, the same findings are in accordance with the results reported in the Middle East between 1980 and 2015 reporting gender differences, and that $75 \%$ of studies reported a high sex ratio in patients with stroke [52]. This is also confirmed by a recent observational study based on the results of the SITS-MENA register, which showed a male predominance (72\%) in MENA countries compared to nonMENA countries (53.6\%) [50]. This result could be due to hormonal factors including estrogen, which seems to have protective effects on both the vascular and cerebral systems [53].

In addition to diabetes, HBP is the main risk factor for IS in Morocco, smoking and heart disease represented the other identified risk factors. In the African context more than half of patients with ischemic stroke had HBP [54]. This joins the results of the literature review of studies conducted in the Middle East between 1980 and 2015, showing that HBP was the most common risk factor, followed by diabetes [52]. These findings are also consistent with data collected in the Eastern Mediterranean countries, where the prevalence of HBP was above $50 \%$ in 38 studies, diabetes percentage was higher than 
$25 \%$ in 36 studies, and smoking was higher than $15 \%$ in 26 studies [51]. The same results are consistent with those found in a recent observational study showing that hypertension, diabetes and smoking were the main risk factors identified in MENA countries [50].

For atrial fibrillation, most of the studies included in the present review demonstrated percentages exceeding $9 \%$. This rate is higher than the proportion recorded in the SITS-MENA register (8.8\%), while atrial fibrillation in non-MENA countries accounted for 19.4\% [50].

The elevated frequency of these vascular risk factors in Morocco could be due to the phenomena of urbanization (60.3\% of the population), and to changes in lifestyle of the Moroccan population [44], as well as to the westernization of the behavior and the food habits between Moroccans [55]. However, a study conducted in the city of Casablanca showed that fast foods have a high composition of sodium and saturated fatty acids and a small concentration of unsaturated fatty acids, contributing thus to the increased prevalence of cardiovascular diseases and stroke in Morocco [56].

Concerning the risk factors of IS between young people, HBP and smoking remains the most reported factors. This can be justified by the fact that Morocco is considered one of the highest tobacco consuming countries in the Mediterranean area with a consumption rate of 15 billion cigarettes each year, and that $42 \%$ of men aged between 30 and 39 years old are smokers [57].

Oral contraception is also a preponderant risk factor between the young subjects. These results can be justified in Morocco by the massive use of hormonal contraceptive methods. For this reason, and according to the performance of the national family planning program established in 2015, the pill represents a percentage of $90 \%$ of all contraceptive used methods [58]. Similarly, a meta-analysis of 16 studies conducted in America in 2015 showed that oral contraceptives are associated with an increased relative risk of cerebral infarction of 2.75 [59].

Genetically speaking, studies have suggested that MTHFR C677T variant could be a determining event of atherothrombotic IS in Morocco, which is perfectly in line with the results reported in a recent meta-analysis showing that the MTHFR C677T mutation increased the risk of IS in adulthood, particularly in atherosclerosis of large arteries [60]. The study by Diakite et al. (2014) suggested a statistically significant association between G894 T polymorphism of eNOS gene and IS, which is consistent with the results of a meta-analysis confirming that G894 T polymorphism of eNOS gene is associated with high risk of IS among Asian populations [61]. Moreover, T-1131C APOA5 mutation could be considered as a genetic risk factor nondependent on IS between the Moroccan population. The same findings were reported in the Chinese population [62]. For SG13S114 ALOX5AP, a significant association was observed in subjects with TT and $\mathrm{T}$ alleles in Morocco. The same result was obtained for the Iberian population [63].

Regarding the etiological classification of TOAST, the present work showed that atherosclerosis of the major arteries is the most dominant etiology. This is probably due mainly to the increased prevalence of HBP and diabetes in the Moroccan population. HBP and diabetes are estimated at $29.3 \%$ and $10.6 \%$, respectively, in addition to poor compliance with antihypertensive therapy or poor glycemic controls, according to the national survey on common risk factors for non-communicable diseases (NCDs) both in 2017 and 2018. In line with this, the percentage of people with HBP who do not take medication in Morocco is estimated at 71.4\% [CI: 69.1-73.7\%]. Furthermore, the proportion of people who have never tested their blood glucose levels is 63.2\% [CI: 61.8$64.6 \%]$ according to the same survey on risk factors common to NCDs [64].

The average prehospital delay for patients with IS in Morocco has ranged between 26 to $61.9 \mathrm{~h}$, which far exceeds the therapeutic window recommended by randomized clinical trials [65].This finding is in accordance with the median admission time $(31 \mathrm{~h})$ mentioned in a review of literature on the African continent [66]. What is more, it joins the average consultation time mentioned in a prospective cross-sectional study conducted at the Center of Brazzaville University Hospital in the Republic of Congo, where they reported a period of $28.2 \mathrm{~h}$ [67]. A longer time period $(16 \mathrm{~h})$ was also recorded in a study conducted at the Sahloul Hospital Center in Sousse, Tunisia [68]. These very long delays listed in our review, were collected mainly in the two university hospitals of Fez and Marrakech and could be explained by the lack of knowledge of the early signs of cerebral infarction. Furthermore, this delay of consultation in the Moroccan population could be linked to the lack of awareness [32,33]. This finding was confirmed by a study conducted at the Mohamed VI University Hospital Center in Marrakech, in which $59.8 \%$ of the interviewees could not name any revealing signs of cerebral ischemia [69]. However, these different findings could probably be due to the elevated illiteracy rate within the Moroccan population $(32.2 \%$ according to the results of the last census) [44]. This could also be explained by the fact that most of the patients arrived at the emergency rooms using personal or common means of transportation (taxi, personal car), and only a minority used ambulance services (3.5\%) [24]. From the same perspective, a recent review demonstrated that low awareness of the signs and symptoms of stroke, the shortage of medical transportation, health care staff and stroke management units, as well as the economic cost of the access to brain imaging facilities and thrombolysis were reported as major obstacles to improve stroke care and stroke management in Africa [66]. 
Concerning the management of IS patients, all thrombolysis-related studies were conducted at the University Hospital of Fez. Therefore, the small percentage of recruited patients could be due, in major part, to the fact that this technique has been recently implemented in the Hassan II University Hospital of Fez [33]. Interestingly, the Daouda study (2017) showed that $11 \%$ of cerebral infarcts did not benefit from thrombolysis because they were admitted after $4.5 \mathrm{~h}$ [24]. Moreover, the Rachdi (2015) study also showed that the majority of patients were not thrombolysed because of the long consultation time and other interfering factors such as the lack of patient's awareness about the clinical signs of IS [28].

Hence, the transportation means (car, taxi, private ambulance), the organizational issues of the emergency medical service (EMS), the difficulties in the recognition of symptoms of IS by the patient, the delays in seeking appropriate emergency care and in obtaining an urgent brain scan and the non-coverage of recombinant tissue plasminogen activator (rt-PA) by the Moroccan National Health System are the main causes involved in the nonaccess of the population to thrombolysis [23].

Moreover, the performance of the Moroccan neurovascular departments is completely in accordance with the data reported in the literature. In this respect, reperfusion treatments (thrombolysis) were administered only to $1-8 \%$ of the admitted patients [70]. A recent metaanalysis showed that only 3\% (95\% CI 2-4\%) of patients were thrombolysed [71].

Indeed, raising the public awareness on a large scale on the neurological signs of the disease are therefore an urgent need, and the organization of pre-hospital medical care from the perspective of reducing admission time and increasing the number of thrombolyzed patients [24].

In addition, the present review revealed that acute mortality ranged from $3 \%$ to $13 \%$. These results are lower than the rates reported in other Arab and African countries [72, 73]. These rates are below the estimated mortality rate described (18\%) in sub-Saharan Africa during the first week of 2013 [74]. These rates are also lower than the one-month overall lethality rates in Middle Eastern countries, which was ranging from 12 to $32 \%$ according to a systematic review between 1980 and 2015 [52]. Similarly, this finding was confirmed by a very recent prospective observational study in the MENA region, showing decreased likelihood of patients death in the MENA with respect to non-MENA countries (6.5 versus $9.6 \%, p<0.001$ ) [75].

Despite the importance of atherosclerotic ischemic and embolic origins in the context of studies of populations, the present critical review demonstrated low rates of lethality and minor rates of occlusion of small arteries [73]. These findings could be due to the implementation of a strategy of diagnosis and effective etiological treatment of cerebral ischemia in the studies we included in our review. Low mortality rates could also be explained by the lack of ischemic stroke studies evaluating mortality rates in Morocco [71]. Three-month mortality in thrombolyzed patients exceeded $20 \%$, according to most studies, which is higher than the mortality rates recorded in a meta-analysis (about 13.4\%) [76].

\section{Limitations}

The present review suffered from several limitations; for example, the studies in question cover only five major cities located in the central parts of the country. We still do not have any data about IS in the north and south of Morocco. Thus, it is difficult to draw any conclusions about the general population. Similarly, most studies were conducted at university hospitals, while most of the Moroccan population has limited access to these facilities. Besides, we should consider the limited access to health care services in rural areas, and the fact that half of stroke patients are not treated in hospitals [77], which exclude a wide range of epidemiological data.

Furthermore, the most of the research on IS was only observation-based studies (Case series and cross-sectional studies), so the authors only tried to describe the patterns of the different variables (risk factors, etiologies...) without using any statistical analysis to reveal potential correlations. Also, the very lacking data originated from the nature of the studies and the implemented local logistics.

Another limitation concerns Moroccan hospital facilities, which mostly receive patients with severe stroke conditions displaying consciousness perturbations and severe hemiplegia [77], decreasing the medical attention toward minor strokes.

\section{Conclusions}

The IS remains a multi-factorial debilitating disorder in Morocco. Overall, available data show a concentration of all studies at university hospitals in metropolitan cities. Also, they suggest that cerebral ischemia is characterized by precocious onset (begins at an early age), male predominance, and etiologies and vascular risk factors observed in patients with IS, which is generally similar to findings in other Arab and African countries. What is more, several genetic markers have been suggested as predisposing factors of cerebral infarction in Morocco. The prehospital delays are very long, compared to the different deadlines listed in developed countries with pathways for the management of IS. Therefore, the expansion of epidemiological studies, particularly in other regions of the country will provide an opportunity to sharpen the incidence and prevalence. Finally, it is high time to further investigate the factors associated with long hospital admission delays in this invalidating pathology to increase the level of brain infarction eligibility for thrombolysis. 


\section{Abbreviations}

AF: Atrial fibrillation; EMS: Emergency medical service; HBP: High blood pressure; IS: Ischemic stroke; MENA: Middle-East and North African; NCDs: Noncommunicable diseases; PRISMA: Preferred reporting items for systematic reviews and meta-analyses; rt-PA: Recombinant tissue plasminogen activator; SITS: Safe implementation of treatments in stroke; TOAST: Trial of ORG classification 10,172 in Acute Stroke Treatment; YIS: Young ischemic stroke

\section{Acknowledgements}

The authors would like to thank Mr. Eloukili Mohamed the curator of the library of the faculty of medicine and pharmacy of Casablanca for his precious collaboration for making medical theses accessible to us. We are grateful to Mr. Achbani Abderrahmane, a member of the Laboratory Cell Biology and Molecular Genetics of the Faculty of Sciences of Ibnozohr University of Agadir, for his collaboration all along the completion of this review. We are also grateful to Dr. Ouhaz Zakaria (Department of Experimental Psychology, University of Oxford, United Kingdom) and Professor Acim Rachid (Ibn Zohr University, Agadir, Morocco) for their assistance in reviewing the quality of the English language manuscript.

\section{Authors' contributions}

KA participated in the conceptualization and design of the review, performed the selection of studies, as well as data extraction, and he drafted the entire review. OM was involved in the conceptualization, the design of the review and data-extraction. OM was involved in the conceptualization and design of the review, data-extraction. She involved in the evaluation of the risk of bias for each included study. Also, she reviewed the article in different phases. LL involved in the evaluation of the risk of bias for each included study, participated in the writing of the protocol of the systematic review. AJ participated in revising the manuscript and more specifically the clinical component. MN participated in revising the manuscript. RR involved in the conceptualization and design of the review, supervised the review, and reviewed the results and the final approval of the manuscript. All authors participated in revising the manuscript and the final approval of the manuscript.

\section{Funding}

There was no funding for this study.

\section{Availability of data and materials}

All data used in the publication of this work were obtained from published studies. Also, the data supporting the conclusions in this article are available in the additional files.

\section{Ethics approval and consent to participate}

Not applicable.

\section{Consent for publication}

Not applicable.

\section{Competing interests}

The authors declare that they have no competing interests.

\section{Author details}

${ }^{1}$ Laboratory of Social Medicine (Public Health, Hygiene and Preventive Medicine), Faculty of Medicine and Pharmacy of Rabat, Mohamed V University, 10100 Rabat, Morocco. ${ }^{2}$ Laboratory of Biostatistics, Clinical Research and Epidemiology (LBRCE), Faculty of Medicine and Pharmacy of Rabat, Mohamed V University, 10100 Rabat, Morocco. ${ }^{3}$ Department of Neurology, International Cheikh Khalifa University Hospital, Mohammed VI University of Health Sciences (UM6SS), 82403 Casablanca, Morocco. ${ }^{4}$ Faculty of Medicine and Pharmacy of Agadir, Ibn Zohr University, 80060 Agadir, Morocco. ${ }^{5}$ Pediatric medical emergencies service of the Children Hospital, 10100 Rabat, Morocco.
Received: 5 August 2019 Accepted: 5 December 2019

Published online: 30 December 2019

\section{References}

1. Tran J, Mirzaei M, Anderson L, Leeder SR. The epidemiology of stroke in the Middle East and North Africa. J Neurol Sci. 2010;295(1-2):38-40.

2. Adeloye D. An estimate of the incidence and prevalence of stroke in Africa: a systematic review and meta-analysis. PLoS One. 2014;9(6):e100724.

3. Campbell BC, Bladin CF, Donnan GA, Davis SM. Acute ischemic stroke. In: Handbook of neuroemergency clinical trials. 2nd ed: Elsevier; 2018. p. 3-21.

4. Streletz L, Mushtak A, Gad H, Abbasi S, Dimassi D, Akhtar N, Mahmoud Y, Dargham S, Abu Raddad L, Khattab AD. Epidemiology of stroke in the MENA region: a systematic review. Int J Neurol Neurol Disord. 2017;1(1):1021 https://bit.ly/2P1qr9h. Accessed 16 Dec 2018.

5. Isabel C, Calvet D, Mas J-L. Stroke prevention. Presse Med. 2016;45(12):e457-71.

6. Engels T, Baglione Q, Audibert M, Viallefont A, Mourji F, Faris MEA, Group GS. Socioeconomic status and stroke prevalence in Morocco: results from the Rabat-Casablanca study. PLoS One. 2014;9(2):e89271.

7. Bruder N, Boussen S. Accident vasculaire cérébral ischémique. Anesth Réanim. 2017;3(1):25-36.

8. Moussaddy A, Demchuk AM, Hill MD. Thrombolytic therapies for ischemic stroke: triumphs and future challenges. Neuropharmacology. 2018;134:272.

9. Blanc-Labarre C, Delpont B, Hervieu-Bègue M, Osseby G-V, Ricolfi F, Thouant P, Giroud M, Béjot Y. Prise en charge aiguë des infarctus cérébraux en 2017. Rev Med Interne. 2018;39(6):408-13.

10. Johnston SC, Mendis S, Mathers CD. Global variation in stroke burden and mortality: estimates from monitoring, surveillance, and modelling. Lancet Neurol. 2009;8(4):345-54.

11. Benamer HT, Grosset D. Stroke in Arab countries: a systematic literature review. J Neurol Sci. 2009;284(1-2):18-23.

12. Moher D, Liberati A, Tetzlaff J, Altman DG. Preferred reporting items for systematic reviews and meta-analyses: the PRISMA statement. Ann Intern Med. 2009;151(4):264-9.

13. Abjaw Z, Zoubir M. Prise en charge des accidents vasculaires cérébraux au service de réanimation de I'hôpital militaire Avicenne. Diabète. 21:25 https:// bit.ly/2DZUwzS. Accessed 21 Nov 2018.

14. Allaoui A, Echchilali K, Bouissar W, Moudatir M, Alaoui F, El Kabli H. Accidents vasculaires ischémiques chez le sujet jeune en médecine interne. Rev Med Interne. 2014;35:A141-2.

15. AMESSAN NDA-Y. Sécurisation du circuit du médicament en milieu hospitalier: expérience dans les accidents vasculaires cérébraux ischémique: Universite Mohammed V; 2010.

16. Belkouch A, Jidane S, Chouaib N, Elbouti A, Nebhani T, Sirbou R, Bakkali H, Belyamani L. Thrombolysis for acute ischemic stroke by tenecteplase in the emergency department of a Moroccan hospital. Pan Afr Med J. 2015;21(1):37.

17. Bendriss $L$, Khatouri $A$. Les accidents vasculaires cérébraux ischémiques. Fréquence des étiologies cardiovasculaires documentées par un bilan cardiovasculaire approfondi. À propos de 110 cas. Ann Cardiol Angeiol. 2012;2012:252-6.

18. Benkirane N, Bennis A, Bellakhdar S, Habbal R, Aidi S, El Alaoui FM, El Otmani H, El Moutawakil B, Rafai MA, Slassi I. Stroke risk factors in a Moroccan population: a multicentric prospective study. J Neurol Sci. 2015;357:e367.

19. Bourazza A, Hsaini Y. Epidemiology study of stroke about 1256 cases. J Neurol Sci. 2013;333:e248.

20. Chraa M, Chaqda M. Risk factors for ischemic stroke, about 442 cases. J Neurol Sci. 2017;381:403-4.

21. Chraa M, Kissani N. Facteurs de risque des accidents vasculaires cérébraux. Rev Neurol. 2015;171:A35.

22. Chraa M, Louhab N, Kissani N. Stroke in young adults: about 128 cases. Pan Afr Med J. 2014;17(1):37.

23. Chtaou N, Rachdi L, El Midaoui A, Souirti Z, Wahlgren N, Belahsen MF. Intravenous thrombolysis with rt-PA in stroke: experience of the moroccan stroke unit. Pan Afr Med J. 2016;24:207.

24. Daouda MT, Bouchal S, Chtaou N, Midaoui A, Souirti Z, Belahsen F. Thrombolysis alert in Hassan II University Teaching Hospital of Fez (Morocco): a prospective study of 2 years. J Stroke Cerebrovasc Dis. 2018; 27(4):1100-6.

25. Chtaou N. Dépistage du syndrôme d'apnées obstructive du sommeil chez les accidents vasculaires cérébraux ischémiques; 2012. 
26. Hadi A, Bendriss L, Khatouri A. L'apport des explorations cardiovasculaires réalisées de manière systématique lors du bilan étiologique d'un AVC ischémique constitué (À propos de 230 cas). Ann Cardiol Angeiol. 2018;67(4):256-9.

27. Rachdi L. Thrombolyse intraveineuse des accidents vasculaires cérébraux : Etude prospective à propos de 40 cas. Thèse de médecine. Université Sidi Mohamed Ben Abdellah, Faculté de médecine et de pharmacie de Fès; 2012

28. Rachdi L. Pronostic des accidents vasculaires cérébraux ischémiques : Etude prospective sur 7 mois, Expérience du service de neurologie, CHU Hassan II Fès. Thèse de médecine. Université Sidi Mohamed Ben Abdellah, Faculté de médecine et de pharmacie de Fès; 2015.

29. Mbagui R. Accidents vasculaires cérébraux ischémiques du sujet jeune étude d'une série de 93 cas; 2009.

30. Chraa M. La prise en charge des accidents vasculaires cérébraux ischémiques. Thèse de médecine. Université Cadi Ayyad, Faculté de médecine et de pharmacie de Marrakech; 2010.p. 1-116.

31. Ibouajbane M. L'accident vasculaire cérébral ischémique du sujet jeune : A propos de 40 cas colligés à l'Hôpital Militaire Molay Ismail. Thèse de médecine. Université Sidi Mohamed Ben Abdellah, Faculté de médecine et de pharmacie de Fès; 2014.

32. Younmadji N. Prise en charge des accidents vasculaires cérébraux ischémiques au service de neurologie du CHU Hassan II : A propos de 1184 Cas. Thèse de médecine. Université Sidi Mohamed Ben Abdellah, Faculté de médecine et de pharmacie de Fès; 2016.

33. Azdad O. Prise en charge des accidents vasculaires cérébraux ischémiques au CHU Hassan II de Fès au cours de cours de la période 2009-2010 : a propos de 1300 cas: Université Sidi Mohamed Ben Abdellah; 2012.

34. Rhissassi M, Amazian K, Chtaou N, Zaama A, Messouaka O, Belahsen M. Le profil épidémiologique des accidents vasculaires cérébraux ischémiques pris en charge au CHU de Fès, Maroc, 2009. Rev Epidemiol Sante Publique. 2010;58:S61.

35. Sarya T. Profil épidémiologique, clinique et étiologique des accidents vasculaires cérébraux ischémiques chez le sujet âgé [Thèse]. Rabat: Université Mohamed V-Souissi; 2013. p. 1-125

36. BALAR K, NADIFI S. Correlation between MTHFR and clinical risk factors in ischemic stroke; 2014.

37. Diakite B, Hamzi K, Hmimech W, Nadifi S. First study of C2491T FV mutation with ischaemic stroke risk in Morocco. J Genet. 2015;94(2):313-5.

38. Diakite B, Hamzi K, Hmimech W, Nadifi S. Genetic polymorphisms of T1131C APOA5 and ALOX5AP SG13S114 with the susceptibility of ischaemic stroke in Morocco. J Genet. 2016;95(2):303-9.

39. Diakite B, Hamzi K, Slassi I, Yahyaoui ME, Alaoui MME, Habbal R, Sellama N. G894T endothelial nitric oxide synthase polymorphism and ischemic stroke in Morocco. Meta Gene. 2014:2:349-57.

40. They-They T, Nadifi S, Rafai M, Battas O, Slassi I. Methylenehydrofolate reductase (C677T) polymorphism and large artery ischemic stroke subtypes. Acta Neurol Scand. 2011;123(2):105-10.

41. They-They TP, Battas O, Nadifi S. Synergistic effect of MTHFR C677T and F2 G20210A polymorphisms on ischemic stroke. Neurosci Bull. 2013;29(6):725-30.

42. N'Drin AYA. Sécurisation du circuit du médicament en milieu hospitalier: expérience dans les accidents vasculaires cérébraux ischémiques; 2010.

43. Allaoui A, Echchilali K, Moudatir M, Alaoui FZ, Elkabli H. Etiologies des accidents vasculaires cérébraux ischémiques chez les jeunes: apport de l'interniste. Pan Afr Med J. 2018;30.

44. Haut commissariat au Plan-Maroc. Recensement général de la population et de l'habitat; 2014.

45. Talbi J, Khadmaoui AE, Soulaymani AE-M, Chafik AE-A. Etude de la consanguinité dans la population marocaine. Impact sur le profil de la santé. Antropo. 2007;15:1-11 https://bit.ly/38lbxlJ. Accessed 15 Jan 2019.

46. Lecoffre C, de Peretti C, Gabet A, Grimaud O, Woimant F, Giroud M. L'accident vasculaire cérébral en France: patients hospitalisés pour AVC en 2014 et évolutions 2008-2014. Bull Epidémiol Hebd. 2017;5:84-94 https://bit. ly/2Rw1fcE. Accessed 25 Jan 2019.

47. Benbekhti S, Chabni N, Henaoui L, Meguenni K. Prise en charge des accidents vasculaires cérébraux au centre hospitalier universitaire de Tlemcen, Algérie. Rev Epidemiol Sante Publique. 2016;64:S240-1.

48. Kefi A, Larbi T, Abdallah M, Ouni AE, Bougacha N, Bouslama K, Hamzaoui S, M'rad S. Young ischemic stroke in Tunisia: a multicentric study. Int J Neurosci. 2017;127(4):314-9.

49. Khan FY. Risk factors of young ischemic stroke in Qatar. Clin Neurol Neurosurg. 2007;109(9):770-3.

50. Al-Rukn S, Mazya M, Akhtar N, Hashim H, Mansouri B, Faouzi B, Aref H, Abdulrahman $\mathrm{H}$, Kesraoui S, Hentati F. Stroke in the middle-east and North
Africa: a 2-year prospective observational study of intravenous thrombolysis treatment in the region. Results from the SITS-MENA registry. Int J Stroke. 2019:1747493019874729.

51. Boutayeb A, Derouich M, Boutayeb W, Lamlili M. Cerebrovascular diseases and associated risk factors in WHO eastern Mediterranean countries; 2014.

52. El-Hajj M, Salameh $P$, Rachidi $S$, Hosseini $H$. The epidemiology of stroke in the Middle East. Eur Stroke J. 2016;1(3):180-98.

53. Sztajzel R, Devuyst G. L'accident vasculaire cérébral chez la femme. Rev Med Suisse. 2002;2:22170 https://bit.ly/38nved1. Accessed 25 Jan 2019.

54. Mensah GA. Epidemiology of stroke and high blood pressure in Africa. Heart. 2008:94(6):697-705.

55. Allali F. Evolution des pratiques alimentaires au Maroc. Int J Med Surg. 2017; 4(1):70-3 https://bit.ly/342TEFc. Accessed 7 Feb 2019.

56. El Kardi $Y$, Jafri A, Anide A, Derouiche A. Composition en sodium et en acides gras saturés et trans dans six type de fast foods au Maroc. Nutr Clin Métab. 2017;31(1):82.

57. Nejjari C, Arharbi M, Chentir M-T, Boujnah R, Kemmou O, Megdiche H, Boulahrouf F, Messoussi K, Nazek L, Bulatov V. Epidemiological trial of hypertension in North Africa (ETHNA): an international multicentre study in Algeria, Morocco and Tunisia. J Hypertens. 2013;31(1):49-62.

58. Ministère de la santé DdIPedRF, Division de la Planification et des Etudes, Service des Etudes et de I'Information Sanitaire: Santé en chiffre. 2016.

59. Gillum LA, Mamidipudi SK, Johnston SC. Ischemic stroke risk with oral contraceptives: a meta-analysis. JAMA. 2000;284(1):72-8.

60. Cui T. MTHFR C677T mutation increased the risk of ischemic stroke, especially in large-artery atherosclerosis in adults: an updated meta-analysis from 38 researches. Int J Neurosci. 2016;126(1):10-9.

61. Niu PP, Yang G, Zheng BK, Guo ZN, Jin H, Yang Y. Relationship between endothelial nitric oxide synthase gene polymorphisms and ischemic stroke: a meta-analysis. Acta Neurol Scand. 2013;128(3):202-12.

62. Xu H, Hu M, Yuan L, Yuan C, Wang Y, Zhang L. Relationship between T1131C polymorphism of apolipoprotein A5 and cerebral infarction in Chinese Han population in Hunan. J Apoplexy Nerv Dis. 2008;25:529-33 https://bit.ly/2YtrTnR. Accessed 13 Feb 2019.

63. Domingues-Montanari S, Fernández-Cadenas I, del Rio-Espinola A, Corbeto N, Krug T, Manso H, Gouveia L, Sobral J, Mendioroz M, Fernández-Morales J. Association of a genetic variant in the ALOX5AP with higher risk of ischemic stroke: a case-control, meta-analysis and functional study. Cerebrovasc Dis. 2010;29(6):528-37.

64. Direction de la l'Epidémiologie et de Lutte contre les Maladies MdlsdM: Enquête nationale sur les Facteurs de Risque communs des Maladies Non Transmissibles 2017-2018. In.; 2019.

65. Larrue VJR. Traitement thrombolytique de l'accident ischémique cérébral. Réanimation. 2001;10(4):392-7.

66. Urimubenshi G, Cadilhac DA, Kagwiza JN, Wu O, Langhorne P. Stroke care in Africa: a systematic review of the literature. Int J Stroke. 2018;13(8):797-805.

67. Ossou-Nguiet P, Gombet T, Ossil-Ampion M, Ellenga-Mbolla B, Otiobanda G, Mahoungou-Guimbi K, Bandzouzi-Ndamba B. Facteurs de mortalité des accidents vasculaires cérébraux au CHU de Brazzaville. RAMUR. 2013;18(1): 15-9 https://bit.ly/2LP1zzN. Accessed 17 Mar 2019.

68. Jemaa HB, Slamia LB, Lammouchi T, Benammou S. Délais de prise en charge des accidents vasculaires cérébraux: Expérience de la région du centre tunisien. Presse Med. 2008;37(10):1502-3.

69. El Mesbahy J, Chraa M, Kissani N. Évaluation des connaissances de la population sur les facteurs de risque et les signes d'alerte de l'infarctus cérébral: enquête à Marrakech. Rev Neurol. 2017;173:S163.

70. Ruiz RG, Fernández JS, Ruiz RMG, Bermejo MR, Arias ÁA, del Saz SP, Arroyo $\mathrm{RH}$, Manero AG, Pinto AS, Muñoz SN. Response to symptoms and prehospital delay in stroke patients. Is it time to reconsider stroke awareness campaigns? J Stroke Cerebrovasc Dis. 2018;27(3):625-32.

71. Khatib R, Arevalo YA, Berendsen MA, Prabhakaran S, Huffman MD. Presentation, evaluation, management, and outcomes of acute stroke in low-and middle-income countries: a systematic review and meta-analysis. Neuroepidemiology. 2018;51(1-2):104-12.

72. Bellalem A, Amroune A, Amiri L, Ayadi N, Maloum D. G-9 épidémiologie des accidents vasculaires cérébraux ischémiques et classification des sous-types selon les critères TOAST à Sétif en Algérie. Rev Neurol. 2007;163(4):18.

73. Touré K, Sawadogo A, Sow A, Basse A, Diagne N, Diop M, Gaye N, Diop A, Cisse $\mathrm{O}$, Seck L. Mortalité des patients hospitalisés pour AVC ischémique en neurologie au CHU de Fann à Dakar. NPG Neurol Psychiatr Gériatr. 2017 ; 17(100):230-4 
74. Balogou A, Guinhouya K, Belo M. Épidémiologie des accidents vasculaires cérébraux en Afrique subsaharienne. Rev Neurol. 2013;169:A244.

75. Rukn SA, Mazya MV, Hentati F, Sassi SB, Nabli F, Said Z, Faouzi B, Hashim H, Abd-Allah F, Mansouri B, et al. Stroke in the middle-east and North Africa: a 2-year prospective observational study of stroke characteristics in the region-results from the safe implementation of treatments in stroke (SITS)middle-east and north African (MENA). Int I Stroke. 2019;14(7):715-722.

76. Graham GDJS. Tissue plasminogen activator for acute ischemic stroke in clinical practice: a meta-analysis of safety data. Stroke. 2003;34(12):2847-50.

77. El Alaoui FM. Les accidents vasculaires au Maroc : Résultats et enseignements d'une enquête épidémiologique. Bulletin d'information de l'académie Hassan II des sciences et techniques, vol. n¹3; 2013. p. 53. https://bit.ly/34XtmFz. Accessed 14 Nov 2019

\section{Publisher's Note}

Springer Nature remains neutral with regard to jurisdictional claims in published maps and institutional affiliations.

Ready to submit your research? Choose BMC and benefit from:

- fast, convenient online submission

- thorough peer review by experienced researchers in your field

- rapid publication on acceptance

- support for research data, including large and complex data types

- gold Open Access which fosters wider collaboration and increased citations

- maximum visibility for your research: over $100 \mathrm{M}$ website views per year

At $\mathrm{BMC}$, research is always in progress.

Learn more biomedcentral.com/submissions 